Provided for non-commercial research and educational use only. Not for reproduction or distribution or commercial use.

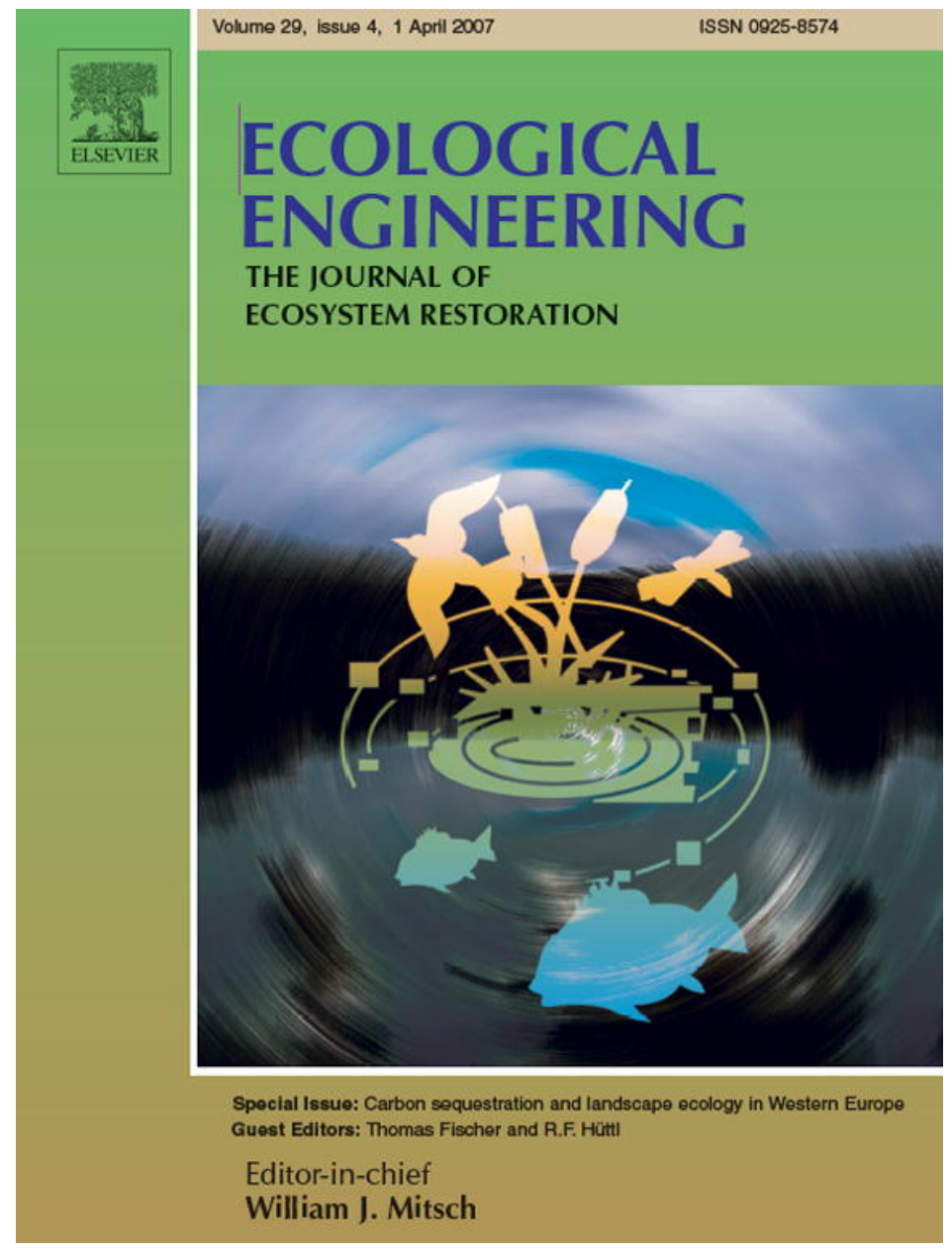

This article was originally published in a journal published by Elsevier, and the attached copy is provided by Elsevier for the author's benefit and for the benefit of the author's institution, for non-commercial research and educational use including without limitation use in instruction at your institution, sending it to specific colleagues that you know, and providing a copy to your institution's administrator.

All other uses, reproduction and distribution, including without limitation commercial reprints, selling or licensing copies or access,

or posting on open internet sites, your personal or institution's website or repository, are prohibited. For exceptions, permission may be sought for such use through Elsevier's permissions site at: 


\title{
Methodological approach for the assessment of environmental effects of agroforestry at the landscape scale
}

\author{
J.H.N. Palma ${ }^{a, *}$, A.R. Graves ${ }^{b}$, P.J. Burgess ${ }^{b}$, K.J. Keesman ${ }^{c}$, \\ H. van Keulen ${ }^{d}$, M. Mayus $^{e}$, Y. Reisner ${ }^{a}$, F. Herzog ${ }^{a}$ \\ a Agroscope Reckenholz-Tänikon Research Station ART, Department for Ecological Controlling, Reckenholzstrasse 191, \\ $\mathrm{CH}-8046$ Zurich, Switzerland \\ ${ }^{\mathrm{b}}$ Institute of Water and Environment, Cranfield University, Silsoe, Bedfordshire MK45 4DT, UK \\ c Wageningen University, Systems \& Control Group, P.O. Box 43, 6700 AA, Wageningen, The Netherlands \\ d Wageningen University, Crop \& Weed Ecology Group, P.O. Box 430, 6700 AK Wageningen, The Netherlands \\ e University of Hohenheim, Faculty of Agricultural Sciences, General Crop Farming, Fruwirthstrasse 123, D-70593 Stuttgart, Germany
}

\section{A R T I C L E I N F O}

\section{Article history:}

Received 31 May 2005

Received in revised form

20 June 2006

Accepted 25 September 2006

\section{Keywords:}

Erosion

Nitrogen leaching

Carbon sequestration

Landscape diversity

Modeling

Alley cropping

\begin{abstract}
A B S T R A C T
Silvoarable agroforestry, the deliberate combined use of trees and arable crops on the same area of land, has been proposed in order to improve the environmental performance of agricultural systems in Europe. Based on existing models and algorithms, we developed a method to predict the environmental effects of SAF at a farm and landscape scale. The method is comprised of an assessment of soil erosion, nitrogen leaching, carbon sequestration, and landscape diversity and allowed the comparison of the environmental performance of SAF with arable systems using these four indicators.

The method was applied to three landscape test sites of $4 \mathrm{~km} \times 4 \mathrm{~km}$ each in Spain, France, and The Netherlands, and compared different levels of agroforestry adoption on farmland of different potential productivity. Silvoarable agroforestry was predicted to reduce soil erosion by up to $70 \%$, to reduce $\mathrm{N}$ leaching by $20-30 \%$, to increase $\mathrm{C}$ sequestration over 60 years by up to 140 tonnes $\mathrm{Cha}^{-1}$, and to increase landscape diversity up to four times. The method developed was executed with widely available landscape and farm structural data and can therefore be applied to other regions in order to obtain a broader assessment of the environmental performance of silvoarable agroforestry systems.
\end{abstract}

๑ 2006 Elsevier B.V. All rights reserved.

\section{Introduction}

Silvoarable agroforestry (SAF) involves the deliberate combination of trees and arable crops on the same land management unit in some form of spatial arrangement or temporal sequence, such that there are significant ecological and economic interactions between trees and arable components (Sinclair, 1999). In temperate environments, SAF has recently attracted interest due to potential environmental benefits as compared with arable systems (Herzog, 2000), especially as reducing negative environmental impacts of agriculture has become a major concern of the European Union's Common Agricultural Policy (CAP) (Buller et al., 2000; Baldock et al., 2002). SAF production systems are also efficient in terms of resource use (Nair, 1993) and are therefore proposed as innovative agricultural production systems that can be both

\footnotetext{
* Corresponding author. Tel.: +41 44377 7664; fax: +41 443777201.

E-mail address: joao.palma@art.admin.ch (J.H.N. Palma).
} 0925-8574/\$ - see front matter @ 2006 Elsevier B.V. All rights reserved. doi:10.1016/j.ecoleng.2006.09.016 
environmentally beneficial and economically profitable. This would improve agricultural sustainability, provide opportunities to diversify farm income, provide new products to the wood industry, and create novel landscapes of high value (Dupraz and Newman, 1997).

Carruthers (1990) stated that agroforestry is an integrated approach that can enhance ecologically sound agricultural production and achieve environmental benefits. Many authors support the view that environmental value can be gained using agroforestry in a European context (e.g. Herzog, 1998; Shakesby et al., 2002). Their statements, however, either relate to observations made in traditional agroforestry systems or are based on conceptual considerations. No systematic investigation of the environmental performance of modern SAF has been conducted so far.

In the context of an European research project of silvoarable agroforestry (SAFE, 2001), four environmental benefits, which can be expected from SAF, were investigated:

(a) Reduction of water-induced soil erosion (hereafter called soil erosion), which can preserve productive soil functions and mitigate the pollution of surface waters with soil particles and absorbed phosphorus and pesticides.

(b) Reduction of nitrate leaching through the formation of a "safety net" of tree roots under the crops and increased water uptake of the system.

(c) Carbon sequestration through the storage in wood not used for combustion.

(d) Increase of landscape biodiversity due to an increased availability of habitats for wild species.

The majority of environmental modeling tools are developed at the point scale, where ecological processes are best understood (Visser and Palma, 2004). However, analysis at a higher scale can better explain environmental phenomena (Grace et al., 1997), and this is particularly the case with agroforestry due to the spatial interaction of tree and crop components. Moreover, agroforestry will typically form only one of several systems of a farm (which may also comprise grassland and arable rotation) as well as of a landscape (which consists of a mosaic of different land-use types).

Therefore, modeling approaches are required which can bridge the gap between the point and the farm- and landscape-scale. To do this, the level of detail of the models needs to be adapted to the spatial resolution of the investigation, in order to minimize modeling error. Fig. 1 illustrates that increasing model complexity and spatial resolution can be associated with an increase in error due to additional data requirements. At the landscape scale, this may be because the data required to derive process-based models of high thematic and temporal resolution are not available and need to be estimated. Hence, at the landscape scale, it is more appropriate to use algorithms which integrate existing knowledge about the processes and are limited to the main governing factors.

In order to assess the previously mentioned environmental effects of SAF, we developed assessment tools based on existing models and algorithms, which were applied in landscape test sites (LTS) of $4 \mathrm{~km} \times 4 \mathrm{~km}$ over a range of geographic situations from Mediterranean to temperate Europe. In this paper, a method to assess the selected environmental effects of SAF is

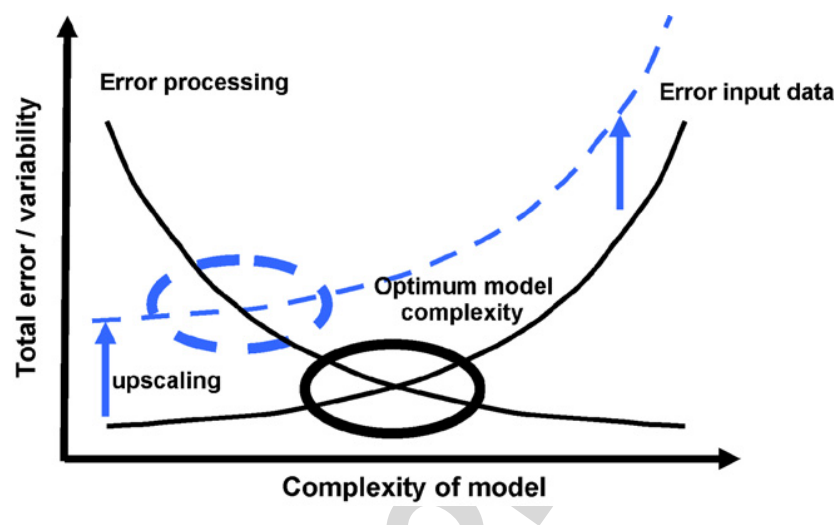

Fig. 1 - Relationship between model complexity and total error in the up-scaling process (source: Wenkel and Schultz, 1999, modified).

explained and illustrated with results from three LTS located in Spain, France, and The Netherlands. These LTS are part of a larger sample described by Graves et al. (2007).

\section{Materials and methods \\ 2.1. Data acquisition and processing}

The investigation was conducted for LTS in Torrijos (Spain), Champlitte (France), and Scherpenzeel (The Netherlands). For each LTS, aerial photographs, taken between 1999 and 2004, were collected and the land use digitized. Soil properties were derived from existing soil maps or through fieldwork and a digital soil map was generated for each LTS. Digital elevation models (DEM) were collected from national sources or developed by digitizing the contour lines of topographic maps. All spatial information was stored and processed in geographic information systems (ArcGIS, ArcInfo ${ }^{\odot}$ and ArcInfo WorkStation $^{\odot}$ 8.3). Daily and monthly weather data (temperature, precipitation, and solar radiation) were generated using Cligen 5.2 (in Lane and Nearing, 1995) from data for the nearest climate station to each LTS, compiled by Global Data Systems (GDS, 2005). Different sources of national agricultural statistics were used to complement data from the farm accountancy data network (FADN) (EC, 2003) and determine the types and typical size of farms present in the LTS.

The main climatic parameters governing resource capture, growth, and production in agroforestry systems were assumed to be precipitation, solar radiation, and temperature (van der Werf et al., 2007). Temperature and precipitation were considered to be homogeneous within the LTS, while solar radiation was assumed to depend on the slope profiles derived from the DEM. The landscape solar radiation grid was calculated with DiGEM (Conrad, 1998) and the radiation in each grid cell was expressed as a proportion of the radiation obtained in a flat, non-shaded grid cell.

The main soil property affecting tree and crop yields was assumed to be the available soil water content. This was estimated from values for soil depth and the soil water release curves identified for different soil textures (van Genuchten, 1980; Wösten et al., 1999). 
Table 1 - Properties of landscape test sites and hypothetical farms for Torrijos in Spain, Champlitte in France, and Scherpenzeel in The Netherlands

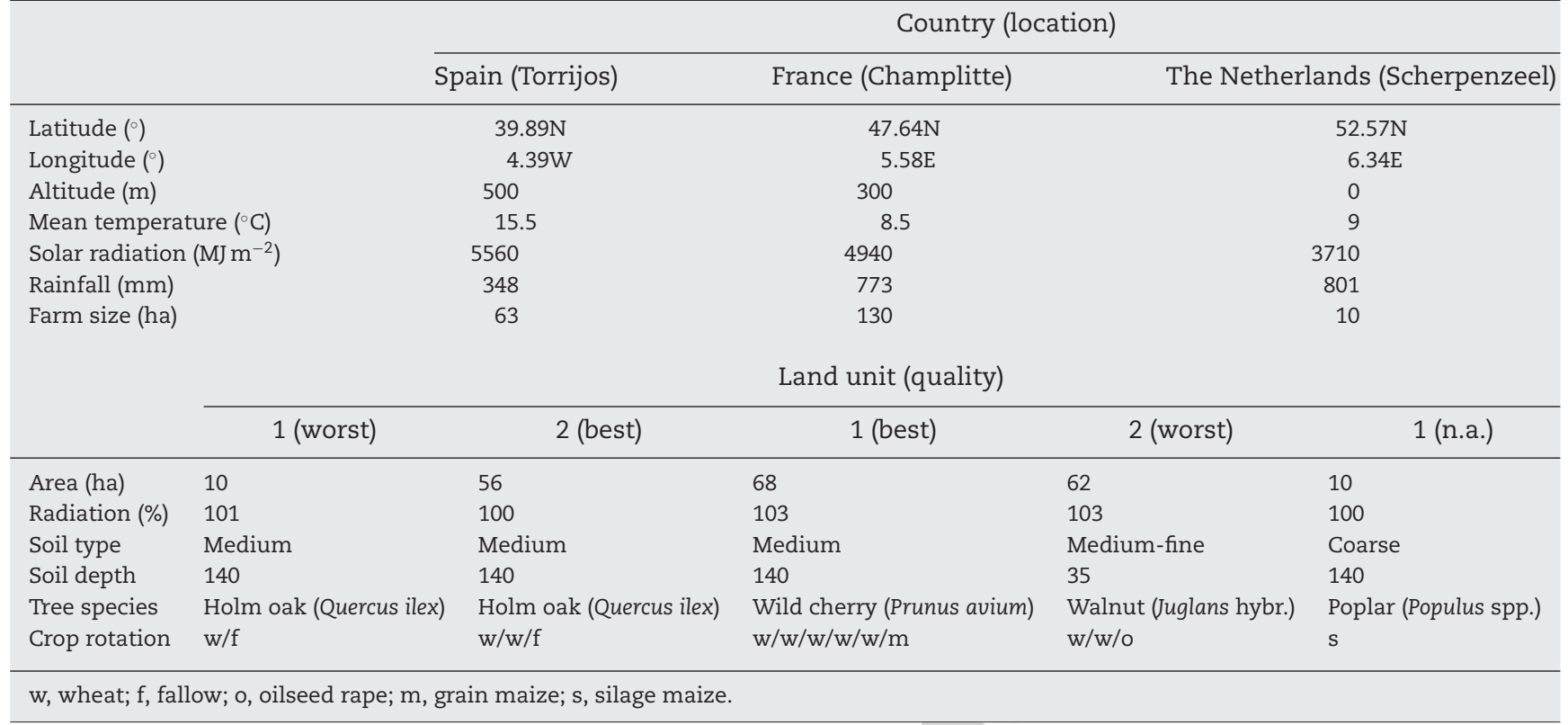

In order to account for spatial variability in solar radiation and available soil water content within each LTS, the LTS was divided into land units (LU) using cluster analysis (Ball and Hall, 1965; Richards, 1986) considering both, solar radiation and available soil water content as variables. Subsequently each LU was characterized by a mean proportion of total solar radiation, the major soil texture and soil depth. This resulted in two LU of different productivity for Torrijos and Champlitte, whereas Scherpenzeel as found to be homogenous (Table 1). All the assessments (except for landscape diversity) were restricted to arable land, as this was considered the target area for SAF. The land units at Torrijos and Champlitte were ranked according to potential productivity, and the crop rotation and agroforestry tree species for each LU were decided in workshops with experts and local stakeholders. The size of a typical farm within each LTS was derived from the FADN $(E C, 2003)$ and from local statistics.

The environmental assessments were undertaken assuming a 60-year rotation of the agroforestry system. Because crop yields within an agroforestry system decline as the trees increase in size and intercept more solar radiation, it was assumed that farmers would stop arable cropping when it was unprofitable. The cut-off point was estimated from a 5-year moving average of profitability (Graves et al., 2007).

\subsection{Assessment of soil erosion}

Erosion processes and concepts are well described (e.g. Morgan, 1995; Terrence et al., 2002) and numerous soil erosion models have been developed (e.g. Wischmeier and Smith, 1978; Morgan et al., 1998). Our assessment was based on the revised universal soil loss equation (RUSLE) (Renard et al., 1997) (Eq. (1)):

$E=R K L S C P$ where $E$ is the soil loss (units: tonnes $\mathrm{ha}^{-1} \mathrm{a}^{-1}$ ), $\mathrm{R}$ the rainfall erosivity factor calculated over 1 year (units: MJ mm ha ${ }^{-1} \mathrm{~h}^{-1} \mathrm{a}^{-1}$ ), $\mathrm{K}$ the soil erodibility factor (units: tonnes $\mathrm{h} \mathrm{MJ}^{-1} \mathrm{~mm}^{-1}$ ), LS the slope-length factor, $C$ the cover management factor, and $P$ the erosion control practice factor. LS, $C$, and $P$ are unitless.

The R-factor was calculated according to van der Knijff et al. (2000), based on a fuzzy interpolation between two models (one for Northern Europe and the other for Southern Europe), which enabled the calculation of the $R$-factor for any latitude of Europe based on mean annual precipitation. For simplicity, precipitation was assumed to be uniform within each LTS, although this may create some error (Lima et al., 2003). The $\mathrm{K}$-factor was derived for each soil map unit based on the texture of the top horizon of the soil (Römkens et al., 1986 quoted in Renard et al., 1997). The Arc Macro Language (AML) used in ArcInfo $^{\odot}$ and developed by van Remortel et al. (2001) was used to compute the LS-factor.

Because SAF has an arable and a forestry component, Eq. (2) was developed to calculate the $C$-factor $(C)$ for agroforestry:

$\mathrm{C}=\left[\right.$ Cover $\left._{\mathrm{a}} \mathrm{C}_{\mathrm{a}}\right]+\left[\right.$ Cover $\left._{\mathrm{f}} \mathrm{C}_{\mathrm{f}}\right]$

where Cover $\mathrm{a}_{\mathrm{a}}$ and Cover $_{\mathrm{f}}$ are the proportions of the total area occupied by the arable and forestry component, respectively (0-1), and $C_{\mathrm{a}}$ and $C_{\mathrm{f}}$ are the related $C$-factors for the arable and forestry component. The values of Cover $a$ and Cover depend on the distance between the tree rows and on the tree row strip width. In the scenarios studied, it was assumed that the agroforestry system comprised 113 trees per hectare and

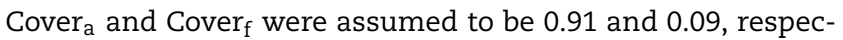
tively. The value of $C_{\mathrm{f}}$ was computed according to Dissmeyer and Foster (1980), and $C_{a}$ was determined for each crop type based on Meyer (1996) and Feldwisch et al. (1998). When the arable rotation was stopped due to unprofitability, $C_{a}$ took the corresponding value for a grass cover. 


\subsection{Assessment of nitrate leaching}

Although the nitrogen cycle in agricultural systems is complex (Whitehead, 1995), relatively simple equations for nitrate leaching can differentiate between different land-use systems at the regional scale. Using the approach of Feldwisch et al. (1998), the quantity of leached nitrogen ( $N_{\text {leach }}$; units: $\mathrm{kgha}^{-1} \mathrm{a}^{-1}$ ) was determined from:

$\mathrm{N}_{\text {leach }}=4.43 \mathrm{~N}_{\text {bal }} \mathrm{EF}$

where $N_{\text {bal }}$ is the nitrogen balance $\left(\mathrm{kg} \mathrm{ha}^{-1} \mathrm{a}^{-1}\right)$ and EF is the annual soil water exchange factor (unitless).

The value of EF depends on the calculated annual flow to groundwater ( $\mathrm{F}_{\mathrm{gw}}$; units: $\left.\mathrm{mm}\right)$, and the soil water content at field capacity (FC; units: $\mathrm{mm}$ ) (Eq. (4)):

if $\frac{F_{\mathrm{gw}}}{F C} \geq 1, \quad$ than $\mathrm{EF}=1 \quad$ if $\frac{F_{\mathrm{gw}}}{F C}<1, \quad$ than $\mathrm{EF}=\frac{F_{\mathrm{gw}}}{\mathrm{FC}}$

Annual values for groundwater recharge were determined by summing daily values for $\mathrm{F}_{\mathrm{gw}}$ derived from a process-based biophysical model called yield-SAFE (van der Werf et al., 2007) which was parameterized and calibrated for the tree species and crop rotation at each LTS (Graves et al., 2007).

The value of the nitrogen balance $\left(\mathrm{N}_{\mathrm{bal}}\right)$ was determined on an annual basis from:

$N_{\text {bal }}=\left(N_{\text {fert }}+A_{\text {dep }}+N_{\text {fix }}+N_{\text {min }}\right)-(D+V+U+I)$

where $N_{\text {fert }}$ is the addition of nitrogen fertilizer (mineral and organic), $A_{\text {dep }}$ the atmospheric deposition, $N_{\text {fix }}$ the biotic nitrogen fixation, $N_{\min }$ the mineralization, $D$ the denitrification, $V$ the volatilization, $U$ the crop/tree uptake and I is the, immobilization (all units in $\mathrm{kg} \mathrm{Nha}^{-1} \mathrm{a}^{-1}$ ).

In long-term assessments with a regular cropping pattern, a steady state equilibrium is expected between mineral nitrogen released by the soil (mineralization) and the amount of nitrogen annually returned to the soil in the form of organic matter (immobilization) (Noy-Meir and Harpaz, 1977; Vlek et al., 1981). Eq. (5) can therefore be simplified to

$N_{\text {bal }}=\left(N_{\text {fert }}+A_{\text {dep }}+N_{\text {fix }}\right)-(D+V+U)$

During the SAF rotation, tree growth and the later conversion to permanent grassland may disturb the $N_{\min }$ - I equilibrium through the addition of organic matter (leaf fall, grassroots). However, yield-SAFE did not allow modeling of these aspects. We assumed that farmers would not account for the slightly increased nitrogen availability under SAF due to leaf fall, whereas under grassland, no nitrogen application was presumed.

The value of $N_{\text {fert }}$ is usually difficult to obtain in studies with a large geographic scope. We therefore adopted the approach used by van Keulen $(1977,1982)$ for determining a relationship between yield and fertilizer inputs for given soil properties. This allowed $\mathrm{N}_{\text {fert }}$ to be derived from the crop and tree yield values predicted by the yield-SAFE model (Graves et al., 2007; van der Werf et al., 2007). For a given crop and tree yield, the nitrogen uptake (U; units: $\left.\mathrm{kg} \mathrm{N} \mathrm{ha}^{-1}\right)$; was estimated as

$U= \begin{cases}\frac{Y_{\mathrm{c}}}{\alpha}+\lambda B_{t} & \text { if } Y_{\mathrm{c}}<\frac{Y_{\max }}{2} \\ \frac{4 Y_{\mathrm{c}}-Y_{\max }}{2 \alpha}+\lambda B_{t} & \text { if } Y_{\mathrm{c}} \geq \frac{Y_{\max }}{2}\end{cases}$

where $Y_{C}$ is the crop yield (unit: $\mathrm{kg} \mathrm{ha}^{-1}$ ), $Y_{\max }$ the maximum crop yield (unit: $\mathrm{kgha}^{-1}$ ), $B_{\mathrm{t}}$ the above-ground tree biomass (unit: $\mathrm{kg} \mathrm{ha}^{-1}$ ), $\alpha$ the slope from quadrant " $a$ " in van Keulen (1982), and $\lambda$ a conversion factor to derive tree nitrogen uptake from $B_{\mathrm{t}}$. The value of $\alpha$ is dependent on the biomass of the straw (S; unit: $\mathrm{kgha}^{-1}$ ) and the harvested product $\left(\mathrm{Y}_{\mathrm{c}}\right)$. A content of 1 and $0.4 \% \mathrm{~N}$ in the grain and straw was assumed, respectively (van Keulen and Wolf, 1986) (Eq. (8)):

$\alpha=\frac{1}{0.01+0.004 S / Y_{\mathrm{C}}}$

The value of $\lambda$ is dependent on the root to shoot ratio of the tree (RSR; unitless), and we assumed 0.66 and $0.41 \%$ concentration of $\mathrm{N}$ in the tree above ground and below ground biomass, respectively (Gifford, 2000a,b) (Eq. (9)). A root to shoot ratio of 0.25 was assumed as proposed by the International Panel on Climate Change (IPCC, 1996) for broadleaved tree species:

$\lambda=0.0066+(0.0041 \mathrm{RSR})$

The fertilizer application was then estimated by

$\mathrm{N}_{\mathrm{fert}}=\frac{\mathrm{U}}{\beta}$

where $\beta$, the recovery factor, is a fraction between 0.5 and 0.8 depending on the management of nitrogen application (van Keulen, 1977, 1982; van Keulen and Wolf, 1986). In all LTS, $\beta$ was assumed to be 0.65 .

$A_{\text {dep }}$ was obtained by summing values of oxidized and reduced nitrogen deposition from EMEP (2003). Values for denitrification $(D)$ were derived from reference tables (Feldwisch et al., 1998) and available water table information. Where no information about the water table in the LTS was available, an average value for $D$ was adopted $\left(30 \mathrm{~kg} \mathrm{Nha}^{-1} \mathrm{a}^{-1}\right)$. As organic fertilization was not considered separately, volatilization (V) was derived from mineral $\mathrm{N}$ application, as in van Keulen et al. (2000) and estimated as $5 \%$ of $N_{\text {fert }}$. As there was no legume crop modeled, $\mathrm{N}_{\mathrm{fix}}$ was estimated for non-symbiotic organisms as $1 \mathrm{~kg} \mathrm{Nha}^{-1} \mathrm{a}^{-1}$ (Wild, 1993).

\subsection{Assessment of carbon sequestration}

Carbon sequestration by the trees $\left(C_{\text {seq }}\right.$; units: $\left.\mathrm{kgha}^{-1}\right)$ was calculated as proposed by Gifford (2000a):

$C_{\text {seq }}=0.5\left(B_{t}+R S R B_{t}\right)$

where $B_{\mathrm{t}}$ is the aboveground tree biomass $\left(\mathrm{kg} \mathrm{ha}^{-1}\right)$, predicted by the yield-SAFE model (Graves et al., 2007). 


\subsection{Assessment of landscape biodiversity}

The introduction of SAF into a predominantly arable landscape will generally increase the diversity of habitats in that landscape. We adopted an index which relates the share of habitat that potentially adds biodiversity to the native species that persist in rural areas. We hypothesized that SAF, with a strong interaction between the permanent (tree) component and the crop component, adds a new habitat to the arable landscape matrix (Burgess et al., 2003). The habitat index (Ihab) was defined as

$I_{\text {hab }}=\frac{A_{\text {hab }}}{A_{\text {total }}}$

where $A_{\text {hab }}$ is the area of non-arable habitats (ha) and $A_{\text {total }}$ is the total area (ha). The value of $A_{\text {hab }}$ was calculated as the area sum of forest, traditional orchards, riparian strips, hedges, shrub land, permanent grassland, fallow land, permanent grassland, and SAF for each LTS.

\subsection{Scenarios}

The LTS is also representative of the hypothetical farm of the dominant type in each of the three regions. We wanted to know whether - in order to generate environmental benefits farmers should implement SAF on a small $(10 \%)$ or a large part $(50 \%)$ of the farm, and whether SAF should be implemented on the most productive ("best land") or least productive ("worst land") sites. These questions were formalized in four scenarios (converting 10 or $50 \%$ of the best land, or 10 or $50 \%$ of the worst land to SAF) which were compared to the present situation ("status quo" arable system). In the context of soil erosion, the effect of contouring practices where farming operations follow the contour lines of the terrain and where trees could be planted along contours was also examined.

For each land unit, an appropriate SAF tree species was selected according to the trees' requirements for profitable growth (Reisner et al., 2007). The crop rotation in the arable system and the crop component of the silvoarable system (Table 1) followed the same status quo rotation, unless the crop component of the silvoarable system became unprofitable, in which case grass was assumed (Graves et al., 2007). Simulations were run over a standard period of 60 years, equivalent to the length of a single life cycle of oak (Quercus ilex), walnut (Juglans hybr.), and wild cherry (Prunus avium) and to three growth cycles of 20-year each for poplar (Populus spp.).

\subsection{Model results interpretation}

The interpretation of the results is to be focused on the relative differences between scenarios rather than on the absolute values. The assessments assumed simple interpolation between plot, farm, and landscape scales, and the appropriateness of this up- and down-scaling has been debated (Bierkens et al., 2000; Stein et al., 2001; Vachaud and Chen, 2002; Visser and Palma, 2004). However, scale research will not be discussed here, although it is recognized as an important issue in model predictions. The objective of this paper was to develop a set of assessment tools and algorithms for major environmental indicators - not to estimate absolute values of soil loss, nitrate leaching, carbon sequestration, and landscape diversity. The emphasis therefore is on possible differences among alternative land-use types, although absolute values are indicated to judge the order of magnitude of the computed values.

\section{Results and discussion}

\subsection{Validity of the approach}

The time frame of assessment was 60 years, longer than the duration of any European silvoarable agroforestry experiment. Moreover, investigations in existing experimental plots mostly deal with productivity (Burgess et al., 2004), and data on environmental performance of SAF systems are scarce. We based the validity of the modeled results on experimental evidence when possible, but we also had to rely on information from the literature.

The importance of taking the uncertainty in model predictions into account is increasingly recognized (Power, 1993; Wallach and Génard, 1998). Uncertainty analysis is an evaluation approach for measuring the reliability of model predictions in order to apply results in decision-making or in land use evaluation. The analysis is performed to reduce the model output imperfections through recognition of possible model improvements. This can be achieved by identifying the essential processes of the model and by investigating which algorithms of the model may need further improvement (Wallach and Génard, 1998; Keesman and Stappers, 2004). Our investigation, however, was focused on identifying differences between scenarios rather than obtaining precise predictions. In agreement, the estimation of uncertainty in the results of the environmental assessments was rather descriptive and qualitative.

However, prior to the application of the newly developed models, the different underlying (sub) tools and algorithms have been evaluated. The evaluation consisted of a rigorous parameterization phase (implementing expert knowledge), a sensitivity analysis, calibration to many different sites and plant species, and/ or a validation phase with experimental data.

\subsection{Assessment of soil erosion}

The calculated soil loss rates in the arable plots of the LTS ranged from 0.5 to 1.8 tonnes ha-1 $\mathrm{a}^{-1}$. These are of a similar magnitude to those indicated in the European soil erosion map (van der Knijff et al., 2000). Although absolute values from an empirical model that has not been locally calibrated should be interpreted with caution (Centeri, 2003), the outputs from RUSLE can still indicate relative differences between alternative land-use types (van Remortel et al., 2001).

In Torrijos and assuming no contouring, RUSLE predicted an annual soil loss of about 1.8 and 0.8 tonnes ha ${ }^{-1}$ for the high (LU2) and low (LU1) quality land, respectively in the arable system (Fig. 2). The fact that the predicted soil erosion was greater on high- than on low-quality land was primarily due to a more intensive rotation on high-quality land. Assuming contouring, the corresponding values were only 1 and 0.5 tonnes ha ${ }^{-1}$. The impact of SAF assuming contouring decreased these values 


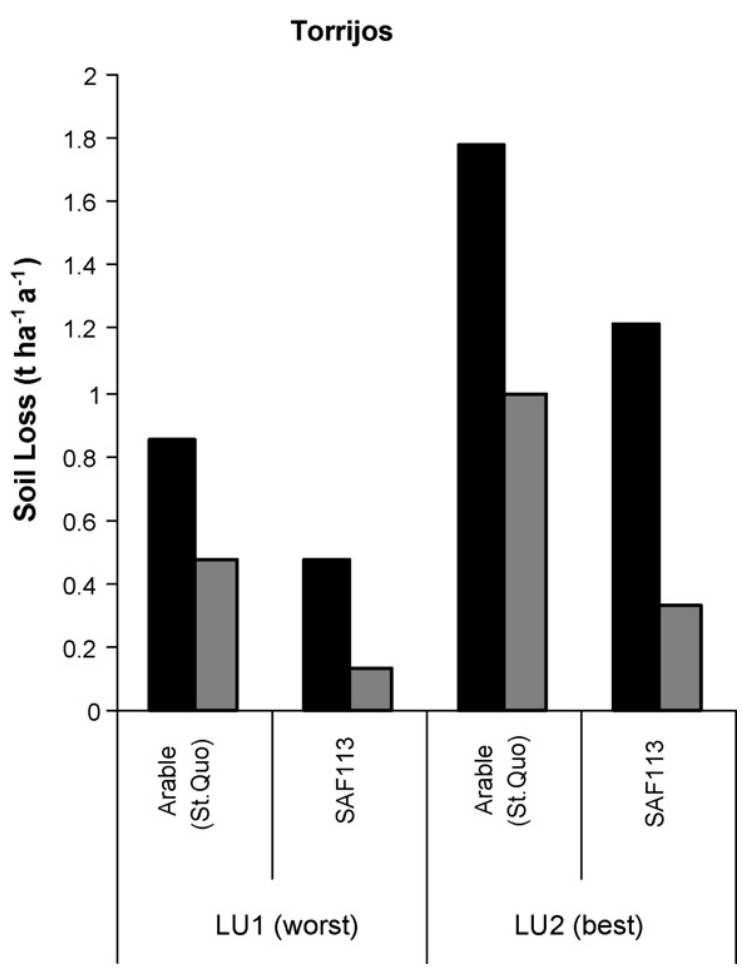

Fig. 2 - Estimated soil loss, at plot scale, for arable systems (St. Quo) and agroforestry $\left(\mathrm{SAF}_{113}\right)$ in the Torrijos landscape test site, central Spain. LU, land unit; see for description of rotations.

to 0.3 and 0.1 tonnes ha ${ }^{-1}$, respectively. A similar benefit has been shown for hedgerow intercropping, where soil erosion was reduced by up to $90 \%$ on gentle slopes in Nigeria, and by $45-65 \%$ on steep slopes in maize systems in Colombia (Young, 1989). The use of RUSLE did not account for gully erosion. In fact, if agroforestry is implemented without contouring, the probability of gully erosion along the tree strips could be increased due to greater erosivity of water drops under the tree canopy (Young, 1989) and this could again compensate for the reduction of soil erosion achieved through SAF.
By using the proportions of the different LU in each LTS (Table 1), the mean annual soil loss was estimated for the arable system for each LTS with and without contouring (Fig. 3). Erosion rates were predicted to be similar in Champlitte and Torrijos (0.8-1.8 tonnes ha $\left.{ }^{-1}\right)$ and lower (0.3-0.5 tonnes ha $\left.{ }^{-1}\right)$ in Scherpenzeel. Contouring practices were consistently projected to reduce erosion. The greatest reduction in soil erosion $(-72 \%)$ was predicted for Champlitte by combining contouring with SAF on $50 \%$ of the farm (Fig. 3 ).

\subsection{Assessment of nitrate leaching}

The assessment of nitrate leaching was based on tree and crop yields over a rotation of 60 years derived from the yield-SAFE model (van der Werf et al., 2007) which was parameterized and calibrated for the selected tree and crop species in each LTS (Burgess et al., 2005). For the low-quality LU in Champlitte, annual crop yield in the arable system ranged from 1.8 to 5.8 tonnes ha ${ }^{-1}$ for wheat and 2.4-3.7 tonnes ha ${ }^{-1}$ for oilseed (Fig. 4a), and tree yield of walnut was assumed to be $69 \mathrm{~m}^{3} \mathrm{ha}^{-1}$ after 60 years (Fig. 4b). This assumed optimum availability of nutrients.

Nitrogen input (Fig. 4c) was estimated from biomass production. In the SAF system, although nitrogen uptake by the trees increased with time, this did not compensate for the reduced nitrogen uptake in the arable component and consequently total uptake in the SAF system was lower than in the arable system (Fig. 4d). However, evapotranspiration for the SAF system was predicted to exceed that for the arable system, resulting in less groundwater recharge (Fig. 4e) and reduced vertical transport of nitrogen. At year 40 , the rotation was stopped due to economic restrictions (Fig. 4a) resulting in a stop of nitrogen fertilization (Fig. 4c). As a consequence, predicted cumulated nitrogen leaching over 60 years was reduced by $40 \%$ (Fig. 4 f).

This approach assumed that $\mathrm{N}$ fertilizer application was always well matched to the yield obtained. This assumption, which holds for both the arable and silvoarable scenarios, is probably realistic, as farmers do modify nitrogen fertilizer management in response to variations in climatic conditions
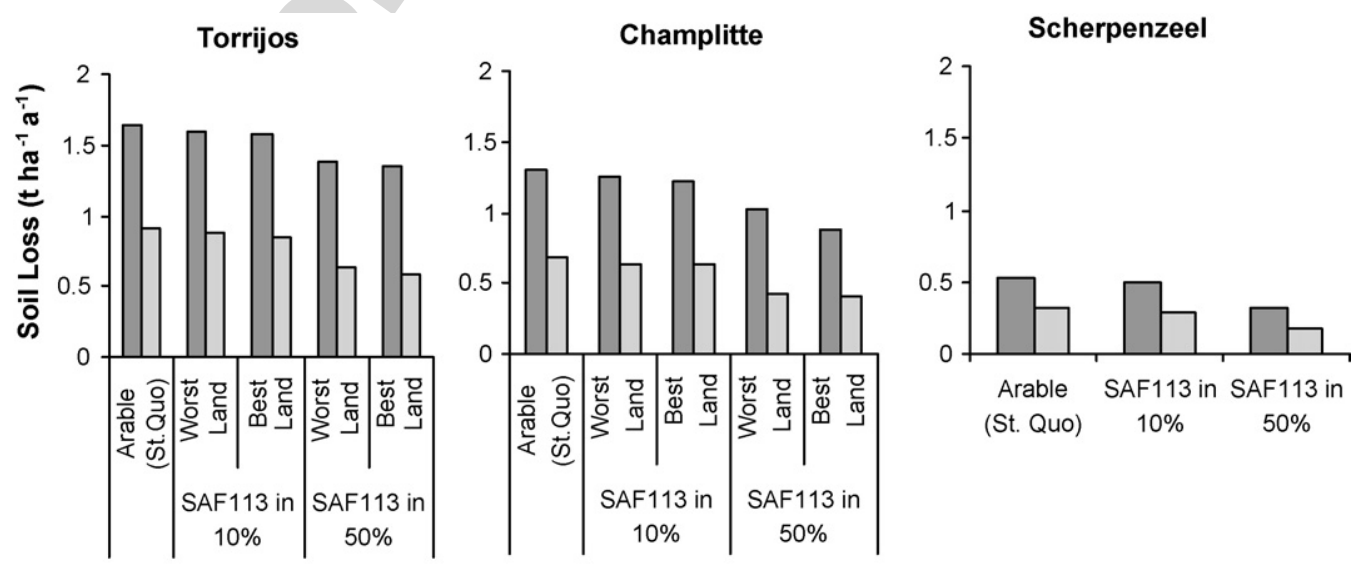

$\square$ Non contouring $\square$ With contouring

Fig. 3 - Estimated soil loss, at farm/landscape scale, for Torrijos (Spain), Champlitte (France), and Scherpenzeel (The Netherlands) for non-contouring and contouring practices. See Table 1 for crop rotations and tree species, section scenarios for definition of scenarios. 
(a)
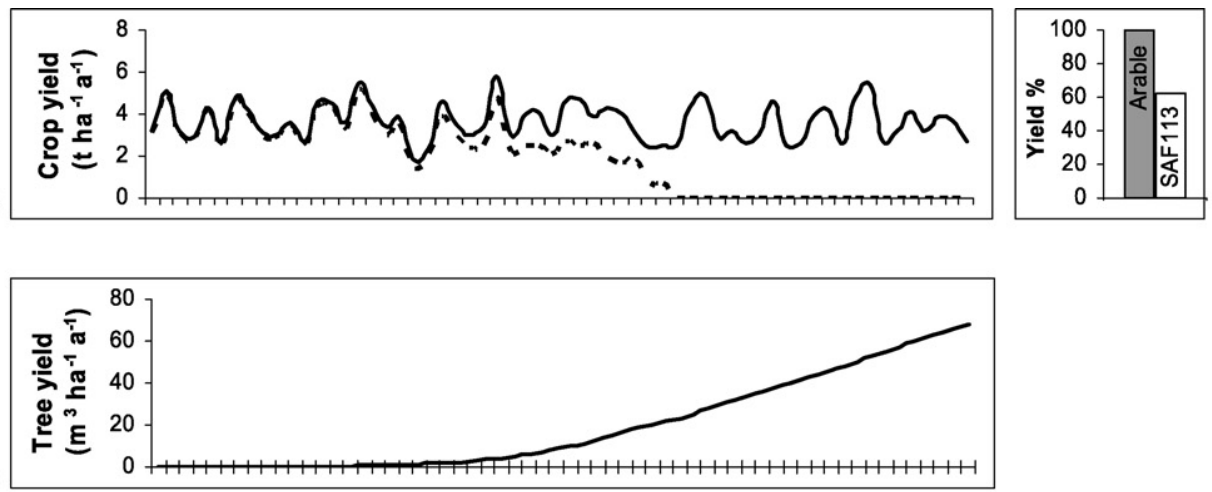

(b)
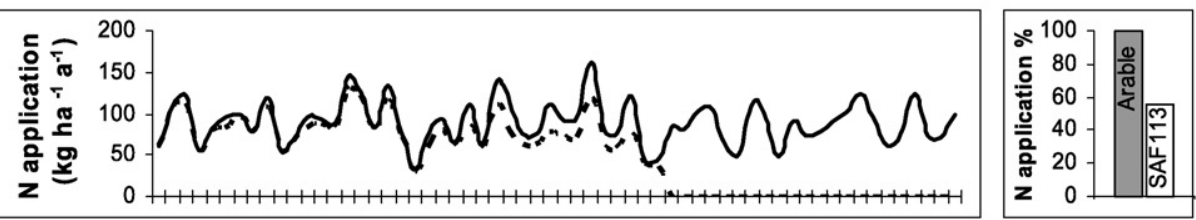

(d)
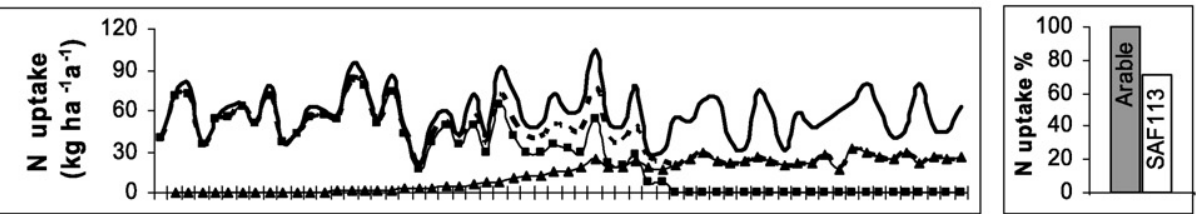

(e)
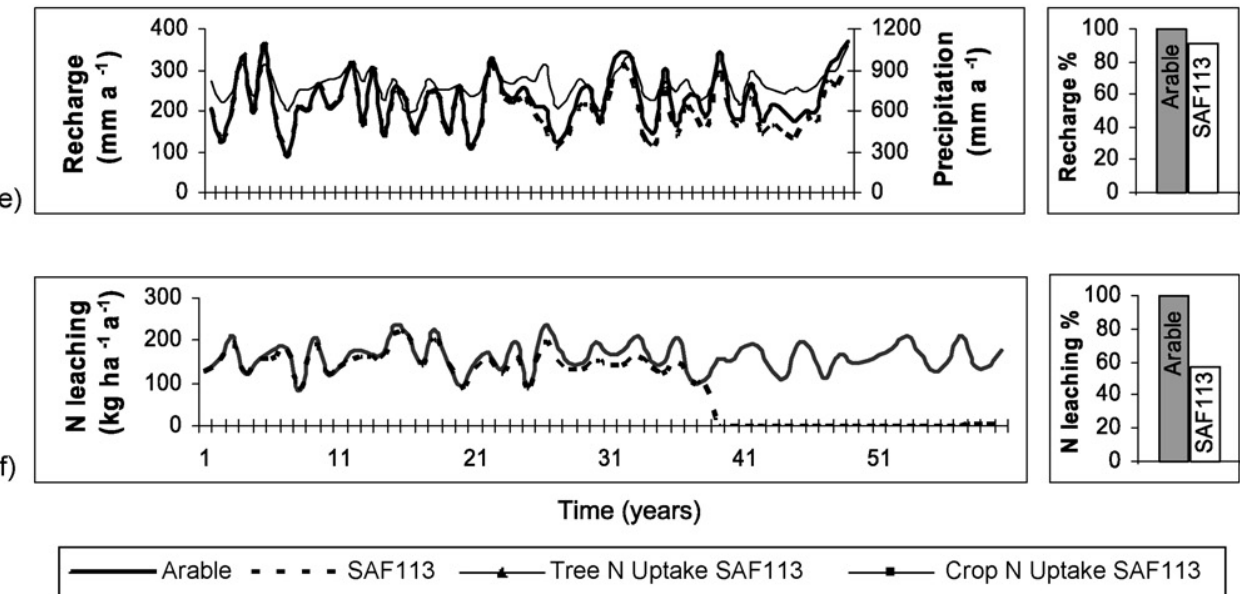

Fig. 4 - Comparison, at plot scale (LU 2), between arable systems and agroforestry $\left(\mathrm{SAF}_{113}\right)$ in the Champlitte LTS, east France. Tree: wild cherry; crop rotation: wheat-wheat-oilseed rape. Soil texture: medium; soil depth: $35 \mathrm{~cm}$. (a) Crop yield; (b) tree yield; (c) N application; (d) N uptake; (e) precipitation and recharge; (f) N leaching. Bar graphs: relative cumulative results for 60 years.

and yield expectations. The reduction in crop yield (Fig. 4a) caused by increasing competition for water and light from the tree is a predictable effect that farmers can take into account when calculating fertilizer input. The calculated relative differences in N-leaching (Fig. 4f) among the scenarios are therefore plausible.

Nitrogen application rates predicted for the three LTS (Fig. 5) were generally lower than or similar to values in the literature. Predicted mean annual application rates for Torrijos were 40 and $36 \mathrm{~kg}$ in land units 1 and 2, respectively. This is within the range reported by Sadras (2002) for rain- fed Mediterranean conditions. In Champlitte, the predicted mean annual applications were $153 \mathrm{~kg}$ in LU 1 and $90 \mathrm{~kg}$ in LU 2 (Fig. 4c). These values are lower than a mean annual application of $160 \mathrm{~kg}$ from nitrogen fertilization statistics for France (Casagrande and Chapelle, 2001). In Scherpenzeel the model predicted a mean annual application of $160 \mathrm{~kg}$ for forage maize. Farmer interviews conducted in the same LTS indicated annual applications of $383 \mathrm{~kg}$ (Herzog et al., 2006).

The predicted mean annual nitrogen leaching under the arable status quo was 0,100 , and $150 \mathrm{~kg} \mathrm{Nha}^{-1}$ in Torrijos, Champlitte, and Scherpenzeel, respectively. No leaching was 
Torrijos

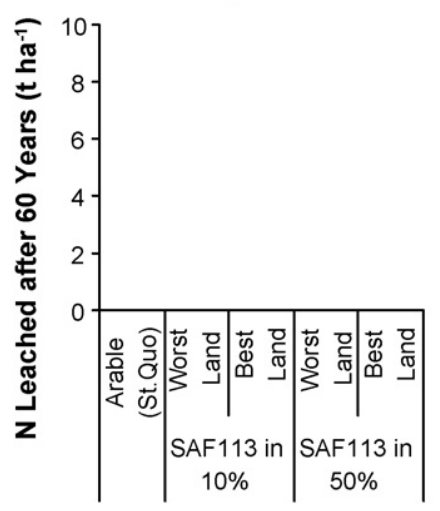

Champlitte

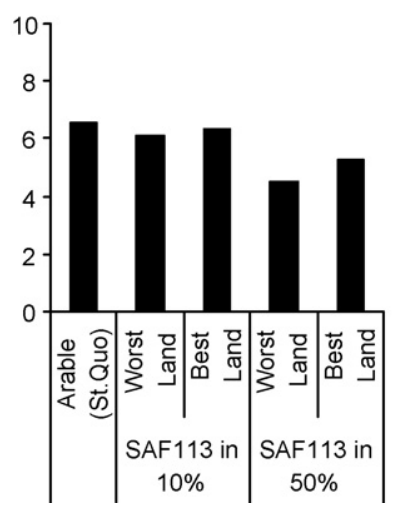

Scherpenzeel

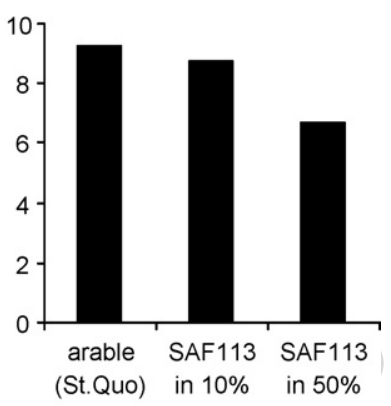

Fig. 5 - Estimated N leaching at the farm/landscape scale, cumulated over 60 years, for Torrijos (Spain), Champlitte (France), and Scherpenzeel (The Netherlands). Note the neglectable leaching in the Mediterranean LTS due to lack of drainage. See Table 1 for crop rotations and tree species, section scenarios for definition of scenarios.

predicted at Torrijos as there was no groundwater recharge and this result agrees well with the general perception that leaching from deep soils under rainfed agriculture in the Mediterranean climate is negligible (Seligman et al., 1992; Sadras, 2002). Typical values for annual N leaching from temperate European locations are $10-80 \mathrm{~kg} \mathrm{ha}^{-1}$ (Nemeth, 1996; Hadas et al., 1999; Ersahin, 2001; Hoffmann and Johnsson, 2003). Slightly higher values of up to $100 \mathrm{~kg} \mathrm{Nha}^{-1} \mathrm{a}^{-1}$ were indicated by Di and Cameron (2002) and Webster et al. (2003). Schröder (1998) reported annual nitrate leaching of $50-250 \mathrm{~kg} \mathrm{~N} \mathrm{ha}^{-1}$ in forage maize systems in sandy soils in The Netherlands.

The analysis predicted that implementing SAF on $50 \%$ of the farm area would reduce cumulative nitrogen leaching over a 60 -year rotation by $30 \%$ at Champlitte and Scherpenzeel (Fig. 5). These reductions appear less than the $40 \%$ reduction reported by Udawatta et al. (2002) in young temperate agroforestry systems for a 3-year period. However, our approach does not account for the potential of the tree roots to recover nitrogen from below the crop rooting zone (Sanchez, 1995; van Noordwijk et al., 1996; Rowe et al., 2001; Udawatta et al., 2002), thus leading to a conservative estimate of the potential reduction in nitrogen leaching.

The introduction of SAF was predicted to show the greatest reduction in nitrogen leaching when implemented on the highest quality land. At Champlitte, this was partly due to the predicted competitive ability of the tree species used on the best land (walnut) being higher than of the tree species on the poor land (wild cherry). For walnut, the biophysical model predicted an earlier impact on the intercrop yield than for cherry, and cumulative leaching was therefore more severely reduced. However, because the worst land (shallower soil) accounted for the majority of the leaching $(76 \%)$ in the whole LTS, the ponderated effect of SAF on the best land at farm/landscape scale is blurred in the cumulated results, which show the best impact in the lowest quality land (Fig. 5, Champlitte). In Scherpenzeel, where land quality was uniform, and a fast-growing tree (Populus spp.) was planted, leaching was reduced by 5 and $30 \%$ when SAF was implemented on 10 and $50 \%$ of the land, respectively (Fig. 5, Scherpenzeel).

\subsection{Assessment of carbon sequestration}

Generally, agroforestry systems sequester less carbon than forestry, but more than grasslands (Lasco and Pulhin, 2004). Lehman and Gaunt (2004) and Harmand et al. (2004) reported that agroforestry systems are unlikely to lead to significant long-term soil carbon sequestration, as organic matter produced is relatively quickly decomposed. Therefore, the main difference in sequestration between an arable system and an agroforestry system lies in the carbon immobilized in the tree biomass (Alegre et al., 2004).

Total carbon sequestered in the tree biomass for each LU was estimated using the above-ground-tree biomass predicted by the yield-SAFE model (Graves et al., 2007) and Eq. (11). Assuming an implementation of agroforestry on half of the area, over a 60-year rotation, the values of carbon were 12 , 43 , and 140 tonnes ha ${ }^{-1}$ in Torrijos, Champlitte, and Scherpenzeel, respectively (Fig. 6). These values are within the range of 3-60 tonnes ha ${ }^{-1}$ for agroforestry systems and 190 tonnes ha ${ }^{-1}$ in poplar forests reported in literature (Kürsten, 2000; van Kooten, 2000; van Kooten et al., 2002; McKenney et al., 2004).

The variation in rate of carbon sequestration among the three LTS was caused by differences in predicted growth rate of the tree species selected at each site. In the low rainfall areas of Spain, holm oak was predicted to grow slowly and sequestration was also low. At Champlitte, for walnut and wild cherry, moderate levels of growth and sequestration were expected. Carbon sequestration, however, was highest for the three 20-year cycles of poplar at Scherpenzeel.

Total carbon sequestration was predicted to increase linearly with increasing proportion of land planted to agroforestry between 10 and 50\% (Fig. 6). Land quality had only a minor effect and further investigations are needed to substantiate these results.

\subsection{Assessment of landscape biodiversity}

Landscape diversity and species diversity are closely linked as additional land-use types, which increase the diversity of landscapes, provide habitats for additional species. Moreover, 

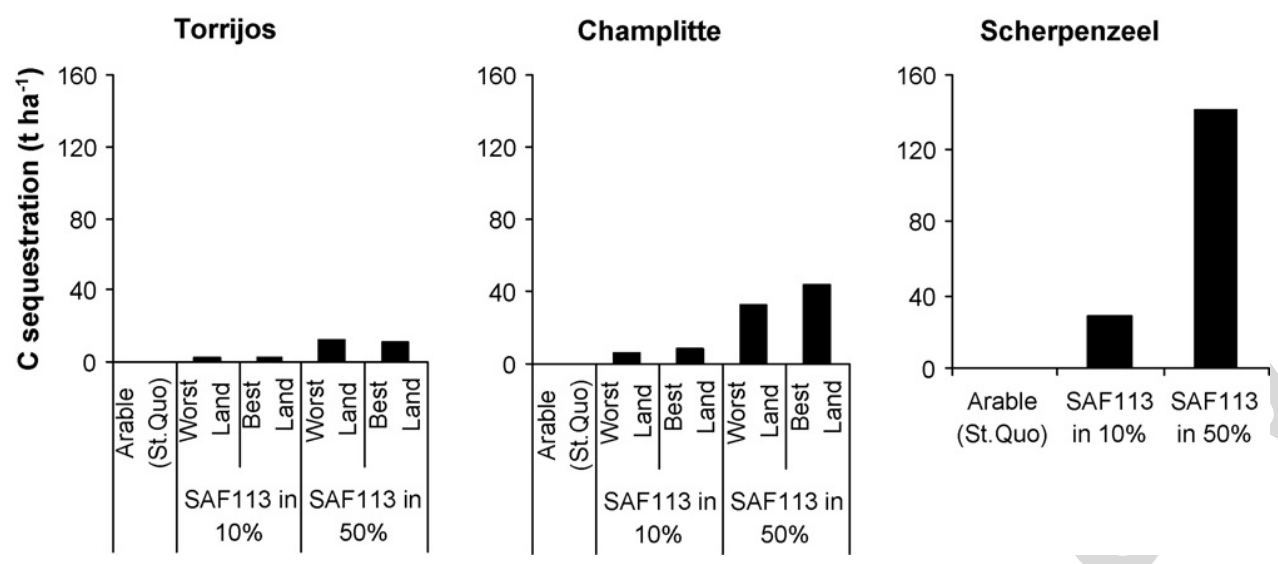

Fig. 6 - Estimated carbon sequestration at the farm/landscape scale, cumulated over 60 years, for Torrijos (Spain), Champlitte (France), and Scherpenzeel (The Netherlands). See Table 1 for crop rotations and tree species, section scenarios for definition of scenarios.

the boundaries between different land-use types (or habitats) multiply and these also consist of specific habitats for some species (Forman and Godron, 1986; Smart et al., 2002).

When considering arable and SAF systems, we assumed that introducing lines of trees in homogeneous arable areas would increase the landscapes' structural diversity and thus potentially their species richness. The trees can provide habitats for some bird and arthropod species. The grassy or herbaceous strip below the trees consists either of sown plant species or of arable weeds; its contribution to species diversity will strongly depend on the management.

To assess the potential impact of SAF on biodiversity at landscape scale, we assumed a direct relationship between biodiversity and the proportion of the area occupied by nonarable (including SAF) and arable habitats (see Eq. (12)). This approach only accounts for landscape composition, and not for its configuration. It is therefore assumed that the increase of natural and semi-natural landscape elements will lead to an increase in biodiversity.

The relative difference between the status quo and the SAF scenarios depends on the habitat areas currently present. Fig. 7 illustrates Eq. (12) and relates the effect of converting different proportions of the arable land (10-90\%) into SAF, and the existing proportion of non-arable habitat (5-90\%).

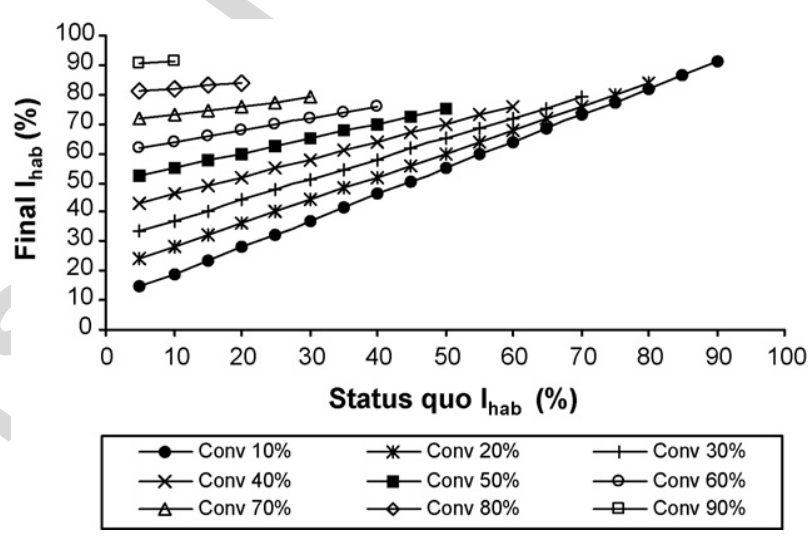

Fig. 7 - Relation between Status quo and final natural and semi-natural habitat index $\left(I_{\text {hab }}\right)$ by converting different proportions of arable land into agroforestry in the farm/landscape. See section scenarios for definition of scenarios.
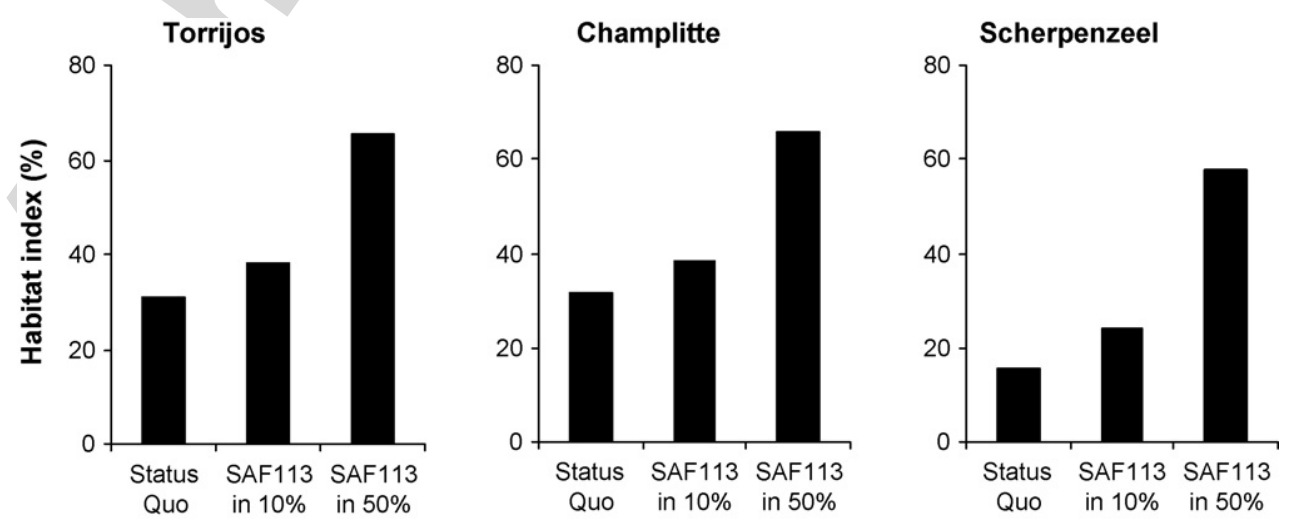

Fig. 8 - Estimated habitat index, at the farm/landscape scale, for Torrijos (Spain), Champlitte (France), and Scherpenzeel (The Netherlands). See section scenarios for definition of scenarios. 
Consequently, in the sites under investigation, introducing SAF had the strongest impact at Scherpenzeel, which had the lowest initial proportion of non-arable habitat. The conversion of $50 \%$ of the farm into SAF increased the proportion of nonarable habitat by $400 \%$ at Scherpenzeel and by $100 \%$ in Torrijos and Champlitte (Fig. 8).

The biodiversity of a new SAF system differs from the existing biodiversity in well established traditional agroforestry systems such as dehesas or traditional orchards (e.g. Anderson and Sinclair, 1993; Herzog, 1998; Plieninger and Wilbrand, 2001; Huang et al., 2002) Their species compositions have evolved over decades, with many species depending on relatively stable conditions and being poor colonizers of new areas (Le Duc et al., 1992). Nevertheless, although further research is needed, recent studies on newly established SAF systems suggest an increase in biodiversity levels (Burgess et al., 2003).

\section{Conclusions and recommendations}

In Europe, positive environmental effects are expected from new land-use systems. The investigation of the environmental performance of land-use systems through experiments, however, is costly - especially at landscape scale. If trees are involved, long-term experimentation requires many years before results are available. Initiation of such experiments becomes increasingly difficult (Poulton, 1995). Therefore the modeling approach described here provided an appropriate method for assessing the environmental effects of agroforestry.

We opted for a broad view which covered four different environmental indicators (soil erosion, nitrogen leaching, carbon sequestration, landscape biodiversity), is applicable over a large geographic range (from Mediterranean to temperate Europe), and is based on the spatial and economic data that are generally available (except for the soil maps in Torrijos, which were based on field work).

Although the model results appear plausible in view of available information from literature, they can be further improved. Erosion could be assessed for different types of tree strip management and algorithms accounting for gully erosion could be added. The nitrogen leaching assessment could be improved by adding mineralization of tree litter or of pruning, which would reduce the rate of fertilization in SAF systems. Moreover, tree N uptake from below the crop rootzone would need to be accounted for. The description of the water balance could be improved by incorporating irrigation (Mayus et al., 2005), this would in turn increase the scope of the model for $\mathrm{N}$ leaching studies. Also, in the future it should be possible to account for the potential access of tree roots to a water table; this would enlarge the range of possible situations which could be investigated. The assessment of carbon sequestration could be complemented with improved carbon allocation models. The estimation of landscape diversity could be complemented by fragmentation indices and by taking into account the spatial allocation of SAF in the landscape supported by field validation and research. More sophisticated approaches, however, require more input data of greater precision to improve the quality of the predictions. We argue that, for the purpose of a broad assessment of the effect of SAF, our approach provides a balance between modeling complexity, the number of indicators and the geographic range under investigation (Fig. 1). The most important activity in improving model predictions would be local validation of input and output data.

The results suggest that SAF could reduce soil loss when introduced on high quality land, where intensive crop rotations are used. Contouring was more effective than SAF in controlling soil erosion, however, the greatest reduction in soil erosion was achieved through the combining SAF and contouring. The results also indicate that SAF could potentially reduce nitrogen leaching. Further investigations are needed to establish the order of magnitude and the influence of tree species and on productivity levels, and thus on the nitrogen cycles. Our predicted $\mathrm{N}$-leaching reductions were conservative, as tree $\mathrm{N}$ uptake from below the crop root-zone was not considered. Whilst carbon sequestration was assumed to be zero in the arable system, some carbon is tied up in the tree component of SAF systems. Carbon sequestration was greater in fast growing species such as poplar than in the slow-growing species like walnut and wild cherry and especially holm oak, which was very slow growing. The very coarse assessment of the potential contribution of SAF to landscape diversity showed greater impact in landscapes where currently arable farming was already dominant and where only few alternative habitats existed.

To validate these preliminary conclusions and to take into account the variability of environmental and socio-economic conditions of landscapes and farms which could potentially adopt SAF systems, we will extend our approach to additional LTS in all three countries, covering thus a gradient from Mediterranean to temperate Europe. Additionally, the results will be linked to the profitability of SAF (Graves et al., 2007) to provide an integrated environmental and economic analysis of SAF (Palma et al., 2006).

\section{Acknowledgements}

Part of this study was funded by the European Union 5th Framework (contract QLK5-2001-00560) and by the Swiss State Secretariat for Education and Research (contract 00.0158). We are grateful to Christian Dupraz for co-coordinating the project and to two anonymous reviewers for their comments on the manuscript.

\section{REFERENCES}

Alegre, J., Krishnamurthy, L., Callo-Concha, D., 2004. Carbon Sequestration by amazonian agroforestry systems. In: Proceedings of the First World Congress of Agroforestry-Book of Abstracts. University of Florida, Institute of Food, Agricultural Sciences, Orlando, USA, p. 162.

Anderson, L., Sinclair, F., 1993. Ecological interactions in agroforestry systems. Agrofor. Abstr. 54 (6), 57-91.

Baldock, D., Dwyer, J., Vinas, J., 2002. Environmental Integration and the CAP. Institute for European Environmental Policy.

Ball, G.H., Hall, D.J., 1965. A Novel Method of Data Analysis and Pattern Classification. Stanford Research Institute, Menlo Park, CA. 
Bierkens, M., Finke, P., Willingen, D., 2000. Upscaling and Downscaling Methods for Environmental Research. Kluwer Academic Publishers, Dordrecht, p. 190.

Buller, H., Wilson, G., Höll, A., 2000. The emergence of regulation 2078. In: Buller, H., Wilson, G., Höll, A. (Eds.),

Agri-Environmental Policy in the European Union. Ashgate Publishing Limited, Aldershot, UK, pp. 1-8.

Burgess, P., Graves, A., Palma, J., Herzog, F., Keesman, K., van der Werf, W., 2005. EU SAFE Project Deliverable 6.4:

Parametrization of the Yield-SAFE Model and its Use to Determine Yields at the Landscape Test Sites. Cranfield University, Institute of Water and Environment, Silsoe, p. 53.

Burgess, P.J., Incoll, L.D., Corry, D.T., Beaton, A., Hart, B.J., 2004. Poplar (Populus spp.) growth and crop yields in a silvoarable experiment at three lowland sites in England. Agrofor. Syst. 63 (2), 157-169.

Burgess, P.J., Incoll, L.D., Hart, B.J., Beaton, A., Piper, R.W., Seymour, I., Reynolds, F.H., Wright, C., Pilbeam, D.J., Graves, A.R., 2003. The impact of silvoarable agroforestry with poplar on farm profitability and biological diversity. Final Project Report to DEFRA.

Carruthers, P., 1990. The prospects for agroforestry-an EC perspective. Outlook Agric. 19 (3), 147-153.

Casagrande, P., Chapelle, C., 2001. Fertilisation azotée minérale: assagissement à la fin des années 80. Agreste Cahiers 2, 3-10.

Centeri, C., 2003. In situ soil erodibility values versus calculations. In: Gabriels, D., Cornelis, W. (Eds.), 25 Years of Assessment of Erosion-International Symposium. International Center for Eremology, University of Ghent, Ghent, pp. 135-140.

Conrad, O., 1998. Derivation of hydrologically significant parameters from digital terrain models. Thesis. University of Göttingen, Göttingen, 91 pp.

Di, H., Cameron, K., 2002. Nitrate leaching in temperate agroecosystems: sources, factors and mitigating strategies. Nutr. Cycl. Agroecosyst. 64 (3), 237-256.

Dissmeyer, G., Foster, G., 1980. A Guide for Predicting Sheet and Rill Erosion on Forest Land. USDA-Forest Service-State and Private Forestry-Southeastern Area, 40 pp.

Dupraz, C., Newman, S., 1997. Temperate agroforestry: the European way. In: Gordon, A., Newman, S. (Eds.), Temperate Agroforestry Systems. CAB International, Cambridge, pp. 181-236.

EC, 2003. FADN, Farm Accountancy Data Network. European Commission.

http://www.europa.eu.int/comm/agriculture/rica/dwh/ index_en.cfm (accessed in 2003).

EMEP, 2003. Cooperative Programme for Monitoring and Evaluation of the Long-range Transmission of Air Pollutants in Europe. www.emep.int (accessed in 2003).

Ersahin, S., 2001. Assessment of spatial variability in nitrate leaching to reduce nitrogen fertilizer impact on water quality. Agric. Water Manage. 48 (3), 179-189.

Feldwisch, N., Frede, H., Hecker, F., 1998. Verfahren zum Abschätzen der Erosions und Auswaschungsgefahr. In: Frede, H., Dabbert, S. (Eds.), Handbuch zum Gewässerschutz in der Landwirtschaft. Ecomed, Landsberg, pp. 22-57.

Forman, R., Godron, M., 1986. Landscape Ecology. John Wiley \& Sons, New York/Chichester/Brisbane/Toronto/Singapore, $619 \mathrm{pp}$.

GDS, 2005. Database of Historical Climate Data Compiled by Global Data Systems. United States Department of Agriculture World Weather Board from World Meteorological Organisation climate reporting systems.

http://hydrolab.arsusda.gov/nicks/nicks.htm (accessed in May 2005).

Gifford, R., 2000a, Carbon Content of Woody Roots: Revised Analysis and a Comparison with Woody Shoot Components. National Carbon Accounting System Technical Report No. 7 (Revision 1), Australian Greenhouse Office, Canberra, 10 pp.
Gifford, R., 2000b, Carbon Contents of Above-Ground Tissues of Forest and Woodland Trees, National Carbon Accounting System. Technical Report No. 22, Australian Greenhouse Office, Canberra, $24 \mathrm{pp}$.

Grace, J., Van Gardingen, P., Luan, J., 1997. Tackling large-scale problems by scaling-up. In: van Gardingen, P., Foody, G., Curran, P. (Eds.), Scaling Up-From Cell to Landscape. Cambridge University Press, Cambridge, UK, pp. 7-16.

Graves, A.R., et al., 2007. Development and application of bio-economic modelling to compare silvoarable, arable and forestry systems in three European countries. Ecol. Eng. 29, 434-449.

Hadas, A., Hadas, A., Sagiv, B., Haruvy, N., 1999. Agricultural practices, soil fertility management modes and resultant nitrogen leaching rates under semi-arid conditions. Agric. Water Manage. 42 (1), 81-95.

Harmand, J.M., Njiti, C., Bernhard-Reversat, F., Olivier, R., Feller, C., 2004. Changes in below ground carbon stocks during rotation "Tree improved fallow-Crops" in the dry tropics of Cameroon. In: Proceedings of the First World Congress of Agroforestry-Book of Abstracts. University of Florida, Institute of Food and Agricultural Sciences, Orlando, p. 182.

Herzog, F., 1998. Streuobst: a traditional agroforestry system as a model for agroforestry development in temperate Europe. Agrofor. Syst. 42 (1), 61-80.

Herzog, F., 2000. The importance of perennial trees for the balance of northern European agricultural landscapes. Unasyiva 200 (51), 42-48.

Herzog, F., Steiner, B., Bailey, D., Baudry, J., Billeter, R., Bukàcek, R., De Blust, G., De Cock, R., Dirksen, J., Dormann, C., De Filippi,

R., Frossard, E., Liira, J., Schmidt, T., Stöckli, R., Thenail, C., Van Wingerden, W., Bugter, R., 2006. Assessing the intensity of temperate European agriculture at the landscape scale. Eur. J. Agron. 24, 165-181.

Hoffmann, M., Johnsson, H., 2003. Test of a modelling system for estimating nitrogen leaching - a pilot study in a small agricultural catchment. Environ. Model. Assess. 8 (1), 15-23.

Huang, W., Luukkanen, O., Johanson, S., Kaarakka, V., Raisanen, S., Vihemaki, H., 2002. Agroforestry for biodiversity conservation of nature reserves: functional group identification and analysis. Agrofor. Syst. 55 (1), 65-72.

IPCC, 1996. Revised 1996 IPCC Guidelines for National Greenhouse Gas Inventories: Reference Manual.

Keesman, K.J., Stappers, R., 2004. Nonlinear set-membership estimation: a support vector machine approach. J. Inversed III: Posed Problems 12 (1), 27-41.

Kürsten, E., 2000. Fuelwood production in agroforestry systems for sustainable land use and $\mathrm{CO}_{2}$-mitigation. Ecol. Eng. 16, S69-S72.

Lane, L., Nearing, M., 1995. USDA-Water Erosion Prediction Project (WEPP): Hillslope Profile and Watershed Model Documentation. NSERL Report \#10, USDA-ARS, West Lafayette, $269 \mathrm{pp}$.

Lasco, R., Pulhin, F.B., 2004. Carbon sequestration of agroforestry systems in southeast Asia: potentials for the clean development mechanism (CDM). In: Proceedings of the First World Congress of Agroforestry-Book of Abstracts. University of Florida, Institute of Food and Agricultural Sciences, Orlando, p. 189.

Le Duc, M.G., Sparks, T.H., Hill, M.O., 1992. Predicting potential colonisers of new woodland plantations. Aspects Appl. Biol. 29, 41-48.

Lehman, J., Gaunt, J., 2004. Carbon sequestration in soils under agroforestry. In: Proceedings of the First World Congress of Agroforestry-Book of Abstracts. University of Florida, Institute of Food and Agricultural Sciences, Orlando, p. 190.

Lima, J., Singh, V., Lima, M., 2003. The influence of storm movement on water erosion. Storm direction and velocity effects. Catena 52, 39-56. 
Mayus, M., Topçu, S., Palma, J., Kirda, C., Herzog, F., van Keulen, H., 2005. Yield-SAFE, for nitrogen application and water management interaction. Calibration and validation for irrigated maize in Mediterranean and Atlantic regions. In: MODSIM05-Proceedings of the International Congress on Modelling and Simulation, Melbourne, Australia.

McKenney, D., Yemshanov, D., Fox, G., Ramlal, E., 2004. Cost estimates for carbon sequestration from fast growing poplar plantations in Canada. For. Policy Econ. 6, 345-358.

Meyer, M., 1996. Erprobung und Anwendung von Methoden zur einzugsgebietsbezogenen Modellierung der Phosphatdynamik terrestrischer Ökosysteme. Thesis. University of Kiel, Kiel.

Morgan, R.P.C., 1995. Soil Erosion and Conservation, 2nd ed. Longman, Harlow, UK, 198 pp.

Morgan, R.P.C., Quinton, J.N., Smith, R.E., Govers, G., Poesen, J.W.A., Auerswald, K., Chisci, G., Torri, D., Styczen, M.E., 1998. The European soil erosion model (EUROSEM): a dynamic approach for predicting sediment transport from fields and small catchments. Earth Surf. Processes Landforms 23 (6), 527-544.

Nair, P., 1993. An Introduction to Agroforestry. Kluwer Academic Publishers, Dordrecht, 494 pp.

Nemeth, T., 1996. Nitrogen balances in long-term field experiments. Fertilizer Res. 43 (1-3), 13-19.

Noy-Meir, I., Harpaz, Y., 1977. Agro-ecosystems in Israel. In: Harper, J., Gruys, P. (Eds.), Agro-Ecosystems, vol. 4. Elsevier Scientific Publishing, Amsterdam, pp. 143-167 (Special Issue).

Palma, J., Graves, A.R., Burgess, P.J., Herzog, F., 2006. Integrating environmental and economic performance to assess modern silvoarable agroforestry in Europe. Ecol. Eco., accepted.

Plieninger, T., Wilbrand, C., 2001. Land use, biodiversity conservation, and rural development in the dehesas of Cuatro Lugares, Spain. Agrofor. Syst. 51 (1), 23-34.

Poulton, R., 1995. The importance of long-term trials in understanding sustainable farming systems: the Rothamsted experience. Aust. J. Exp. Agric. 35, 825-834.

Power, M., 1993. The predictive validation of ecological and environmental models. Ecol. Model. 68, 33-50.

Reisner, Y., et al., 2007. Target regions for silvoarable agroforestry in Europe. Ecol. Eng. 29, 401-418.

Renard, K., Foster, G., Weesies, G., McCool, D., Yoder, D., 1997. Predicting Soil Erosion by Water: A Guide to Conservation Planning with the Revised Universal Soil Loss Equation (RUSLE). US Department of Agriculture, USDA Agricultural Handbook No. 703.

Richards, J.A., 1986. Remote Sensing Digital Image Analysis. An Introduction. Springer-Verlag, Berlin/Heidelberg/New York.

Römkens, M., Prasad, S., Poesen, J., 1986. Soil erodibility and properties. In: Proceedings of the XIIIth Congress of the International Society of Soil Science, vol. 5, Hamburg, Germany, pp. 492-504.

Rowe, E.C., van Noordwijk, M., Suprayogo, D., Hairiah, K., Giller, K.E., Cadisch, G., 2001. Root distributions partially explain N-15 uptake patterns in Gliricidia and Peltophorum hedgerow intercropping systems. Plant Soil 235 (2), 167-179.

Sadras, V., 2002. Interaction between rainfall and nitrogen fertilisation of wheat in environments prone to terminal drought: economic and environmental risk analysis. Field Crops Res. 77 (2/3), 201-215.

SAFE, 2001. Silvoarable Agroforestry For Europe-European Union 5th Framework Project Through the Contract QLK5-2001-00560. http://www.montpellier.inra.fr/safe/.

Sanchez, P.A., 1995. Science in agroforestry. Agrofor. Syst. 30 (1/2), 5-55.

Schröder, J., 1998. Towards improved nitrogen management in silage maize production on sandy soils. Thesis. Wageningen Agricultural University, Wageningen, 223 pp.
Seligman, N., van Keulen, H., Spitters, C., 1992. Weather, soil conditions and the interannual variability of herbage production and nutrient uptake on annual Mediterranean pastures. Agric. For. Meteorol. 57, 265-279.

Shakesby, R.A., Coelho, C.O.A., Schnabel, S., Keizer, J.J., Clarke, M.A., Contador, J.F.L., Walsh, R.P.D., Ferreira, A.J.D., Doerr, S.H., 2002. A ranking methodology for assessing relative erosion risk and its application to dehesas and montados in Spain and Portugal. Land Deg. Dev. 13 (2), 129-140.

Sinclair, F.L., 1999. A general classification of agroforestry practice. Agrofor. Syst. 46 (2), 161-180.

Smart, S.M., Bunce, R.G.H., Firbank, L.G., Coward, P., 2002. Do field boundaries act as refugia for grassland plant species diversity in intensively managed agricultural landscapes in Britain? Agric. Ecosyst. Environ. 91 (1-3), 73-87.

Stein, A., Riley, J., Halberg, N., 2001. Issues of scale for environmental indicators. Agric. Ecosyst. Environ. 87 (2), 215-232.

Terrence, J., Foster, G., Renard, K.G., 2002. Soil Erosion: Processes, Prediction, Measurement and Control. John Wiley \& Sons, New York, $238 \mathrm{pp}$.

Udawatta, R.P., Krstansky, J.J., Henderson, G.S., Garrett, H.E., 2002. Agroforestry practices, runoff, and nutrient loss: a paired watershed comparison. J. Environ. Qual. 31 (4), 1214-1225.

Vachaud, G., Chen, T., 2002. Sensitivity of a large-scale hydrologic model to quality of input data obtained at different scales; distributed versus stochastic non-distributed modelling. J. Hydrol. 264 (1-4), 101-112.

van der Knijff, J.M., Jones, R.J.A., Montanarella, L., 2000. Soil erosion Risk Assessment in Europe. European Commission. European Communities, Brussels.

van der Werf, W., et al., 2007. Yield-SAFE: a parameter-sparse process-based dynamic capture, growth and production in agroforestry systems. Ecol. Eng. 29, 419-433.

van Genuchten, M.T., 1980. A closed-form equation for predicting the hydraulic conductivity of unsaturated soils. Soil Sci. Soc. Am. J. 44, 892-898.

van Keulen, H., 1977. Nitrogen Requirements of Rice with Special Reference to Java. Contributions Central Research Institute for Agriculture, Bogor, $67 \mathrm{pp}$.

van Keulen, H., 1982. Graphical analysis of annual crop response to fertilizer application. Agric. Syst. 9, 113-126.

van Keulen, H., Aarts, H., Habekotte, B., van der Meer, H., Spiertz, J., 2000. Soil-plant-animal relations in nutrient cycling: the case of dairy farming system 'De Marke'. Eur. J. Agron. 13 (2/3), 245-261.

van Keulen, H., Wolf, J., 1986. Crop production as determined by nutrient availability. In: Modelling of Agricultural Production: Weather, Soils and Crops. Simulation Monographs, Pudoc, Wageningen, pp. 153-181.

van Kooten, G., Shaikh, S., Suchánek, P., 2002. Mitigating climate change by planting trees: the transaction costs trap. Land Econ. 78 (4), 559-572.

van Kooten, G.C., 2000. Economic dynamics of tree planting for carbon uptake on marginal agricultural lands. Can. J. Agric. Econ. 48, 51-65.

van Noordwijk, M., Lawson, G., Soumaré, A., Groot, F., Hairiah, K., 1996. Root distribution of trees and crops: competition and/or complementary? In: Huxley, P. (Ed.), Tree-Crop Interaction: A Physiological Approach. University Press, Cambridge, pp. 319-364.

van Remortel, R., Hamilton, M., Hickey, R., 2001. Estimating the LS factor for RUSLE through iterative slope length processing of digital elevation data within ArcInfo GRID. Cartography 30 (1), 27-35.

Visser, S., Palma, J., 2004. Upscaling wind and water erosion models. Far from reality? In: Visser, S., Cornelis, W. (Eds.), Wind and Rain Interaction in Erosion-Tropical Resource 
Management Papers, vol. 50. Wageningen University and Research Center, Wageningen, pp. 59-67.

Vlek, P., Fillery, I., Burford, J., 1981. Accession, transformation, and loss of nitrogen in soils of the arid region. Plant Soil 58, 133-175.

Wallach, D., Génard, M., 1998. Effect of uncertainty in input and parameter values on model prediction error. Ecol. Model. 105, 337-345.

Webster, C.P., Conway, J.S., Crew, A.P., Goulding, K.W.T., 2003. Nitrogen leaching losses under a less intensive farming and environment (LIFE) integrated system. Soil Use Manage. 19 (1), 36-44.

Wenkel, K.-O., Schultz, A., 1999. Vom Punkt zur Fläche-das Skalierungs-bzw. Regionalisierungsproblem aus der Sicht der Landschaftsmodellierung. In: Volk, M., Steinhardt, U. (Eds.),
Regionalisierung in der Landschaftsökologie. Stuttgart, Leipzig, Teubner, pp. 19-42.

Whitehead, D.C., 1995. Nitrogen Grassland. CAB International, Wallingford, $416 \mathrm{pp}$

Wild, A., 1993. Soils and the Environment: An Introduction. Cambridge University Press, Cambridge.

Wischmeier, W., Smith, D., 1978. Predicting Rainfall Erosion Losses-A Guide to Conservation Planning. Agriculture Handbook No. 537. US Department of Agriculture.

Wösten, J., Lilly, A., Nemes, A., Le Bas, C., 1999. Development and use of a database of hydraulic properties of European soils. Geoderma 90, 169-185.

Young, A., 1989. Agroforestry for Soil Conservation. CAB International, Wallingford, UK. 